\title{
Design and Building Mikrotik Based Billing System and Chatbot as Media Transaction Online
}

\author{
I Made Adhiarta Wikantyasa ${ }^{\mathrm{a} 1}$, I Made Agus Dwi Suarjaya ${ }^{\mathrm{a} 2}$, I Made Sunia Raharja ${ }^{\mathrm{a} 3}$ \\ ${ }^{a}$ Program Studi Teknologi Informasi, Fakultas Teknik,Universitas Udayana, \\ Bukit Jimbaran,Bali, Indonesia \\ E-mail: ${ }^{1}$ wikantyasa@student.unud.ac.id, ${ }^{2}$ agussuariaya@it.unud.ac.id, ${ }^{3}$ sunia.raharia@gmail.com
}

\begin{abstract}
Abstrak
Menyediakan layanan pada user jasa rt/rw net jika dilakukan secara manual akan mengabiskan waktu yang cukup banyak. Pada layanan ini masih menggunakan cara yang konvensional walaupun adanya aplikasi yang membantu tetapi masih tetap belum efisien dalam menyediakan kebutuhan yang diperlukan oleh pengguna seperti dalam melakukan transaksi masih menggunakan voucher berbasis kertas yang akan menyulitkan penyedia untuk menyediakan waktu untuk menangani transaksi pengguna. Selain dari sisi transaksi ada juga kelemahan dimana akan menyulitkan calon pengguna dalam menghubungkan penyedia layanan dikarenakannya beberapa yang membuka jasa ini tidak terlalu mengerti dalam mengedit halaman mikrotik yang akan mengakibatkan kesulitan admin dalam memperomosikan jasa mereka serta menginfokan kontak mereka. Dengan masalah yang dibahas diusulkan sebuah aplikasi yaitu "Rancang Bangun Aplikasi Webisite Mikrotik Berbasis Billing Sistem Dan Chatbot Sebagai Media Transaksi Online". Dengan terciptanya aplikasi ini dapat mempermudah admin dalam menyediakan kebutuhan pengguna yaitu menginfokan mengenai jasa yang disediakan serta berinteraksi dengan admin dengan menggunakan chatbot sebagai media penyambung dan transaksi online untuk memudahkan pengguna untuk memperbarui paket internet mereka serta admin dalam mengolah transaksi pengguna.
\end{abstract}

Kata kunci: Billing Sistem, Chabot, Mikrotik Api, Hotspot

\begin{abstract}
Providing services to rt / rw net users if done manually will consume a lot of time. Currently this service still used conventional methods even though there are applications that can help but still not efficient in providing the needs of the users such as transactions still using paper based vouchers, which will make it difficult for providers to provide time to handle user transactions. Besides that, there are also a problem where potential users of the service find a hard time to contact the provider because lack of knowledge of some of the provider to edit the mikrotik page to inform about their service and themselves to the user. With the problems mentioned, an application is needed that can provide much easier solution namely, "Design and Building Mikrotik Based Billing System and Chabot as Media Transaction Online". By making this application, it can provide much better solution for user such as getting information and interacting with the admin by using Chabot as media and online transaction to make it easier for users to update their packets and admin to process user transaction.
\end{abstract}

Keywords: Billing System, Chat Bot, Mikrotik Api, Hotspot

\section{Introduction}

Information technology at this time has developed rapidly where current users no longer need to do manual work which takes a long time and is inefficient to get or find the desired information with information technology, information management can be done in a more actual manner and optimal [1].The RT / RW net business is one of the trends in the development of internet technology which is the same as other internet providers, namely (indihome, biznet and other ISP) where this network provides internet facilities by implementing network tools in various housing or blocks but with a smaller reach. This network usually uses Mikrotik devices in processing users who buy vouchers and providing bandwidth and configuration of each connected device, but in the rt / rw net business there are still some things that are still inefficiently done by 
service providers in providing the needs of users who use their services, one of which is namely transactions are still carried out manually, where if the user's internet package has run out, therefore the user must visit the internet provider to buy a new internet package and handle user requests such as filing complaints and potential customers asking about their services, because some who open this service do not Having basic knowledge about html, therefore it will be difficult to edit the proxy page provided according to their wishes to tell potential customers to contact the provider to get information about their services [2] [3].Apart from that there are also deficiencies in the device section that need license level 5 higher to access the user manager feature for much easier to manage user that connected to hotspot and if the admin forcefully install the user manager package the hardware can't handle because of the low memory that it got. [4]. Based on the problems that exist in this background, the writer provides a solution with the title "Designing a Mikrotik-Based Website Billing System and Using a Bot Line Messenger as an Online Transaction Tool". By creating this application will provide as a tool to assist admins in processing and handling service user problems as well as transactions made by service users towards adding points or purchasing internet packages and for bot line messenger as a transaction tool for purchasing internet service packages and online conversation media for users to the admin.

\section{Research Method / Proposed Method}

In designing a Mikrotik-based billing system and using a bot line messenger as a medium for online transactions, the research method used is the Waterfall method [5], which includes design analysis, program code writing, testing and maintenance. This section will discuss more clearly, namely an overview of system, system design requirement, design interface, design database and testing

\subsection{System overview}

An overview of system is a process that provides a basic overview of an application that is made to find out what output and input will be processed in the application being made. The following is an overview of the application created [6].

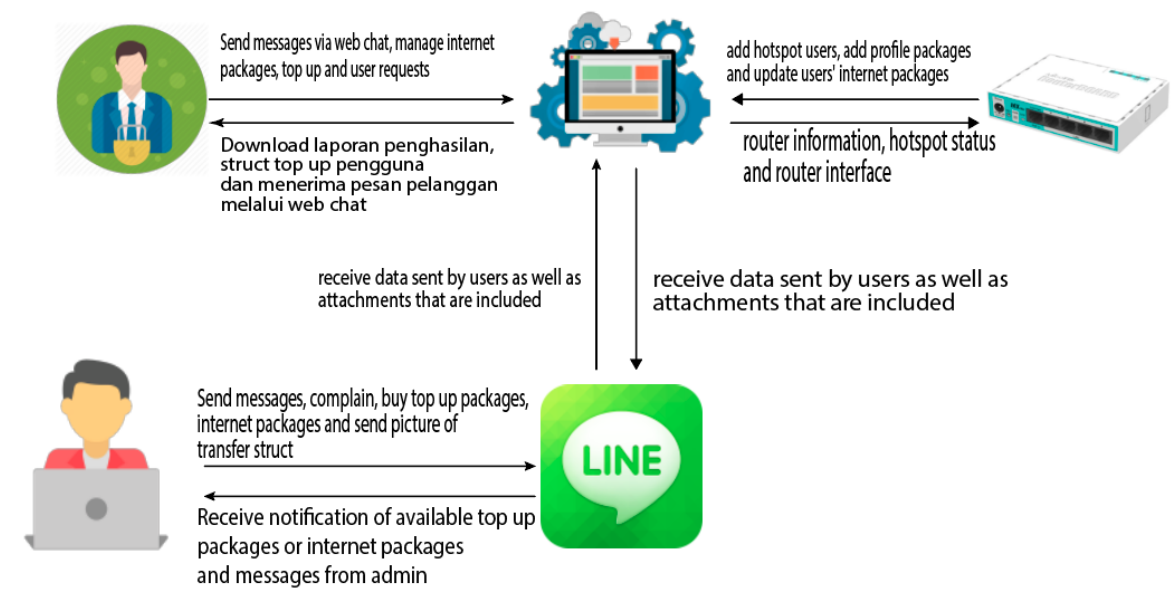

Figure 1 System overview

Figure 1 show the system overview that start by the admin access the website then each activity that involve of saving data or changing the status of data will go through the database of the website but each activity that involve the mikrotik hardware will pass through the hardware first through library that it used. Activity that it include that is making mikrotik account, update packets internet user and making new packet internet and from the user side each request that it send will go through the line api that will send the request through web hook to function in the main website to process the data that it need and from this function will send it back to the user. 


\subsection{Design System Requirement}

The design system requirement is to determine the needs of the system and the output and input of data used in the design of this website application, the design of this system will provide a diagram of the use case to provide a functional picture of the system.

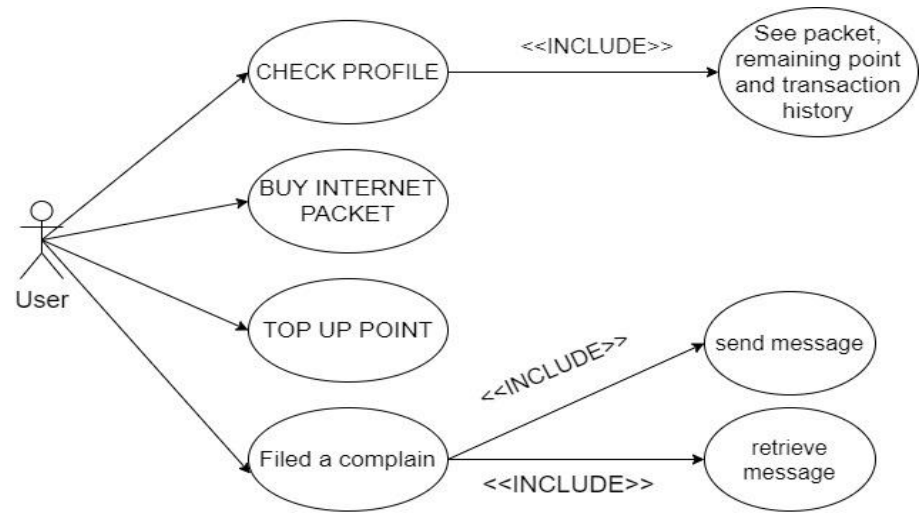

Figure 2 Use Case User

Figure 2 shown about how use case of user inside this system that show user can see their profile information like seeing the packets they using, point they have and history transaction they have. For the next three use case user can buy packets internet, buy packets point and request complain to start conversation with admin from that user can send message and retrieve message.

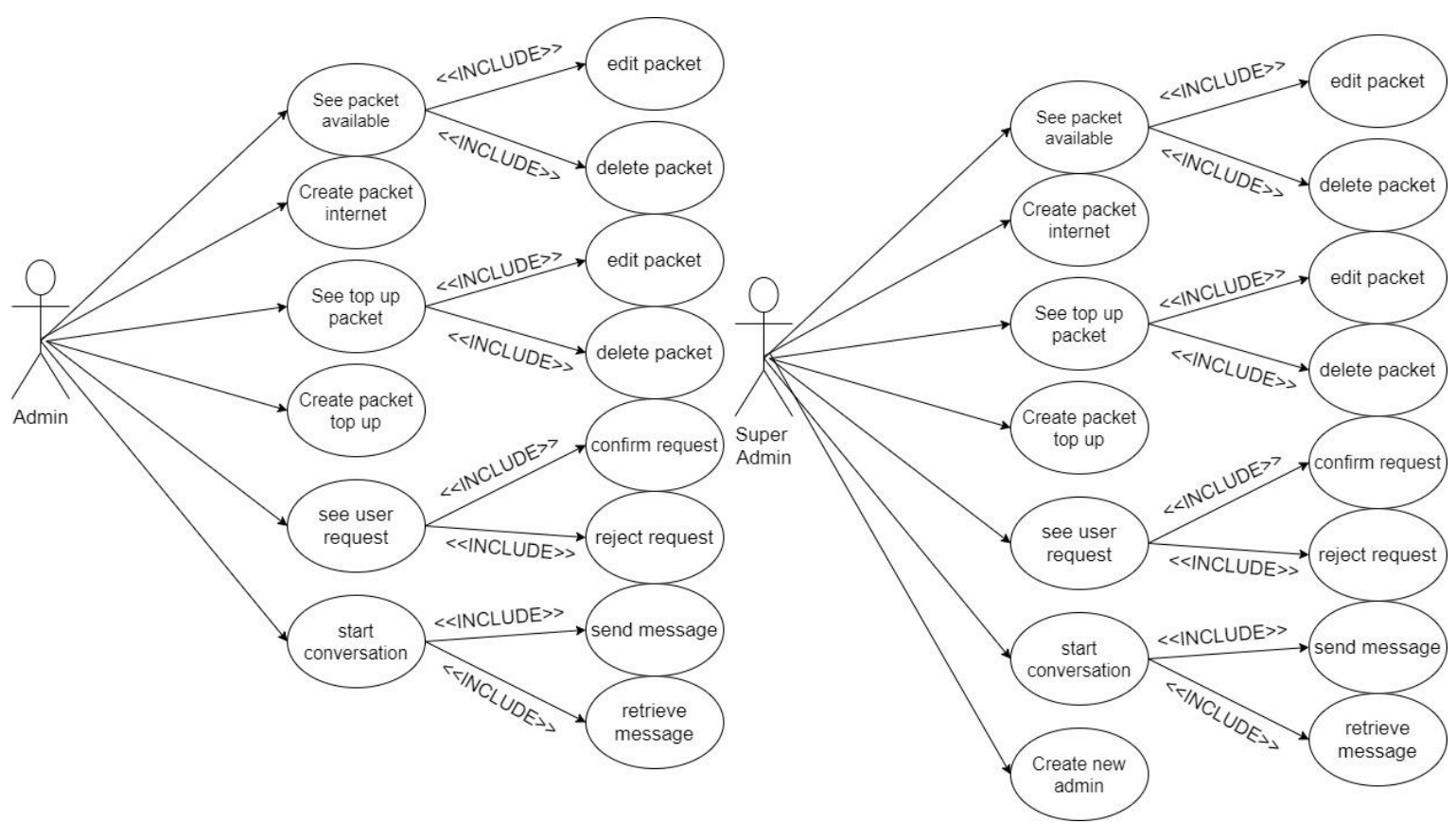

Figure 3 Use Case Admin And Super Admin

Figure 3 shown about how role admin and super admin in this system from seeing the use case above the difference between this two use case is that the super admin can made another admin but from that the role of this two is the same that is manage packet internet or top up, made packets internet or topup, send or retrieve message and confirm request that is confirmation account mikrotik, confirmation packets point and confirmation complain.

\subsection{Design Interface}


Interface design is something that must be done to create an actual and optimal system from the features previously described. By designing the system, it can provide an idea of how the system will be displayed and how a design will make it easier for users to use this application.
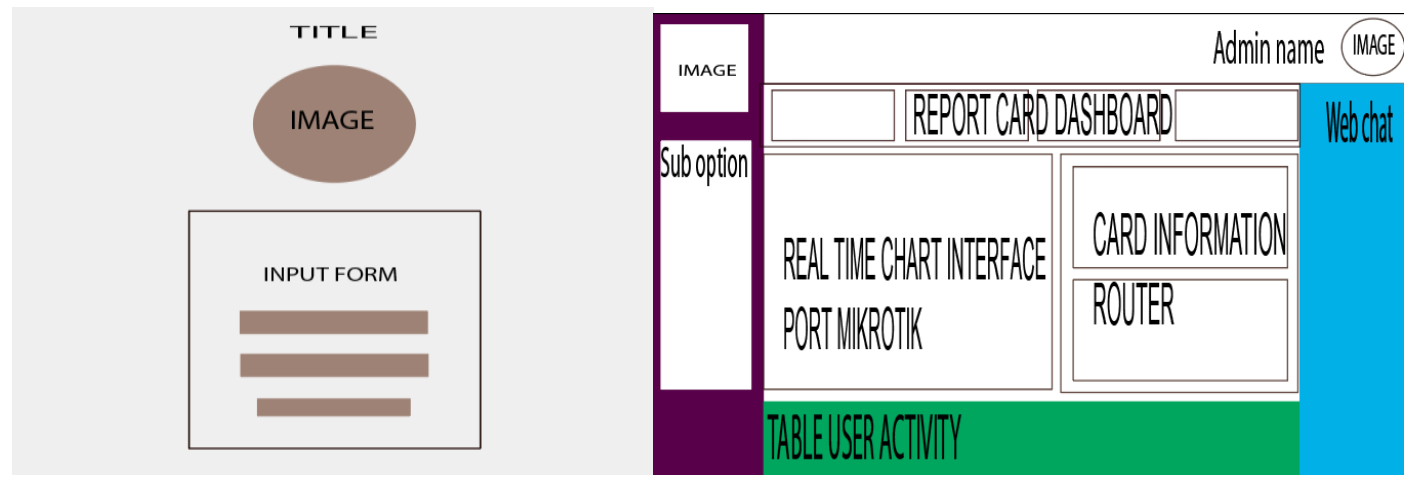

Figure 4 Design login page and dashboard

The design of login page website and mikrotik login that can be seen at left image at figure 4, admin have to get through this two page to start using the system and the design of the dashboard interface can be seen at right image at figure 4, this page is a starting page that used for seeing the overview of the activity of user that active using the network and see the traffic status of each active port in hardware mikrotik.

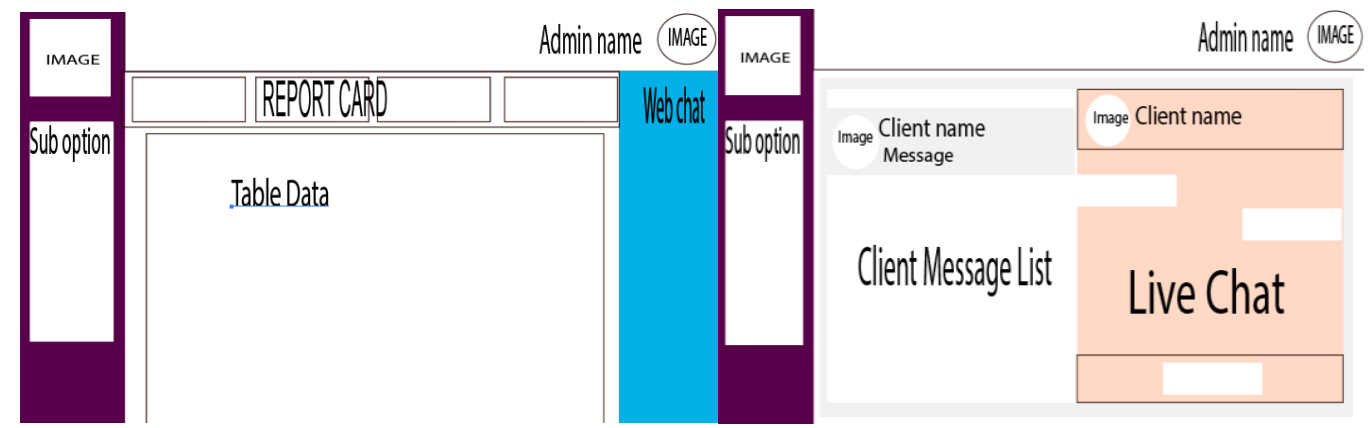

Figure 5 Social, use rmanager and web chat

The design of social and user manager can be seen at left image at figure 5 , social and use rmanager page is a view of a two feature that used for manage packet point and packet internet as well as for manage request complain that user give and the second image is for web chat page that can be seen at right image of figure 5 , for this page it used for when admin start conversation with user that give the complaint request.
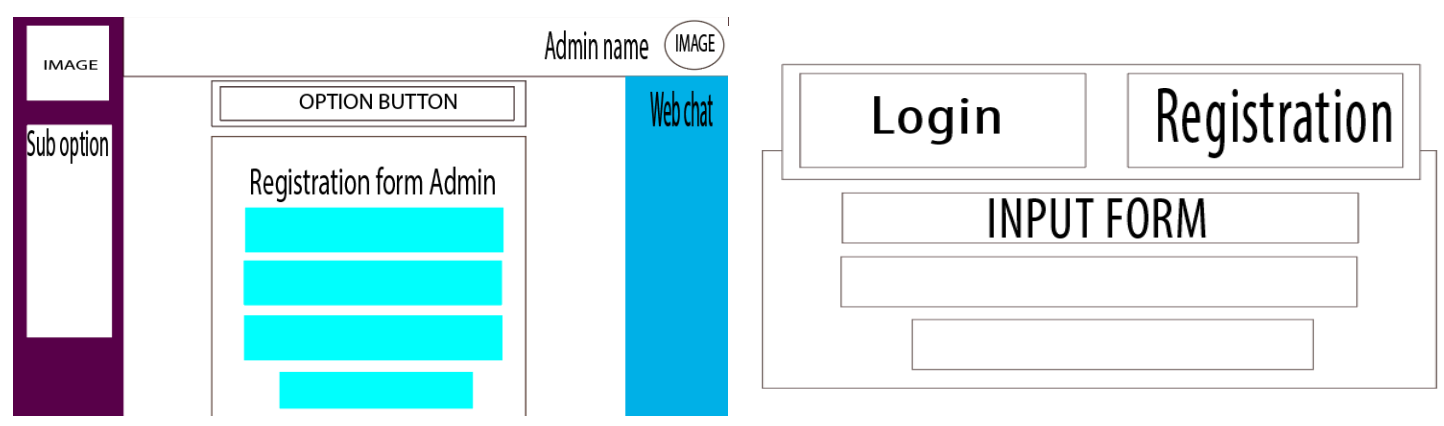

Figure 6 Design admin manager and login mikrotik 
The design of admin manager and mikrotik hotspot can be seen at at figure 6 , admin manager page it used for manage created admin as well as for created new admin and the mikrotik hotspot page that can be seen at the right of figure 6 is used for landing page for user to access the network or register to access the network.

\subsection{Design Database}

Database is a collection of data items that are related to one another organized according to a certain schema or structure, which can be recovered quickly and easily [7]. At this stage it aims to display the table required in the system that being designed, that can be seen at figure 8 .

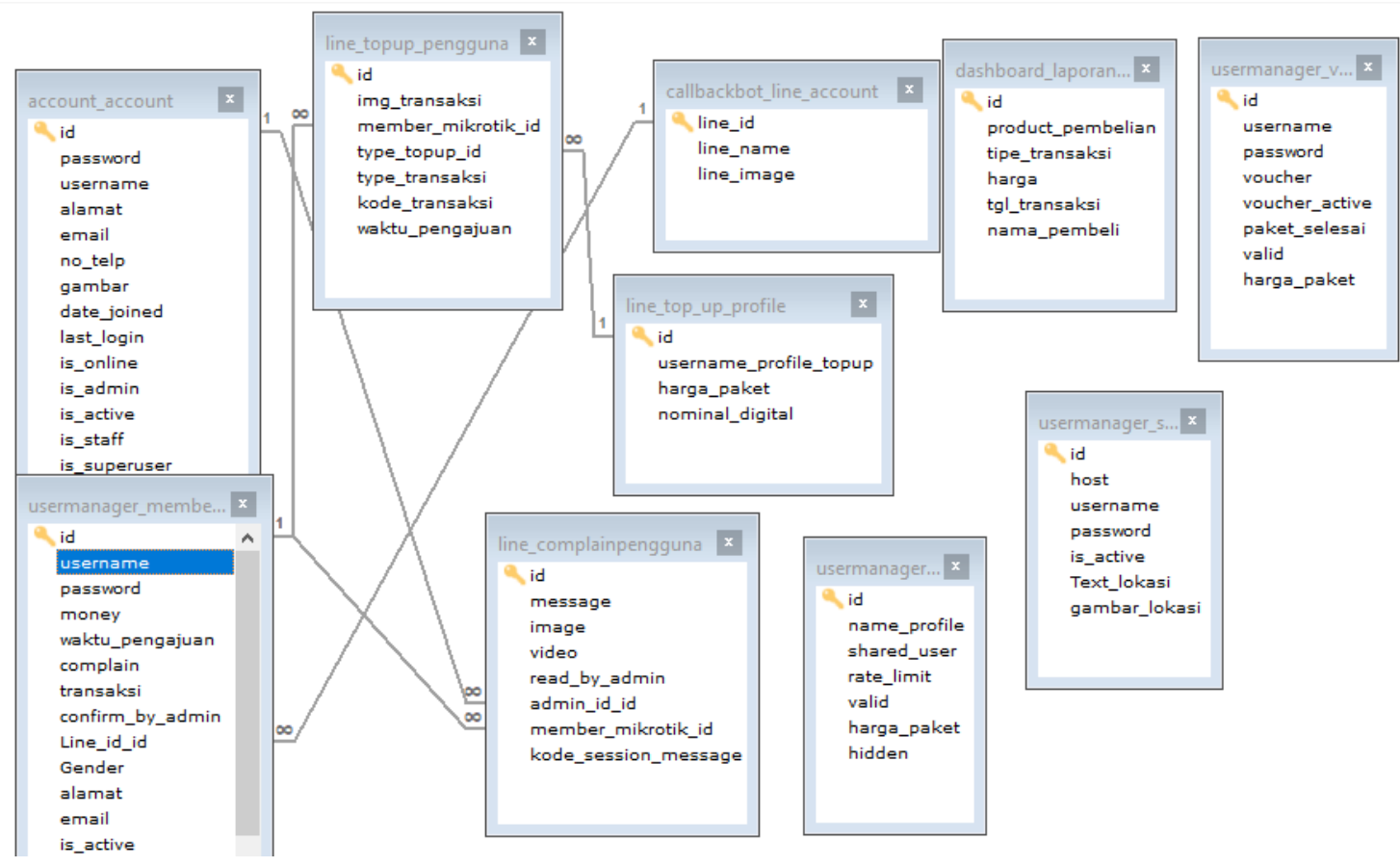

Figure 7 Design Database

Figure 7 is the PDM used in this billing system which coinsists of ten tables, namely account_account,line_complainpengguna,line_topup_profile,line_topup_pengguna,usermanager_ member_mikrotik,usermanager_packet_profile,usermanager_server_pembayaran_paket,userman ager_voucher_member_mikrotik,dashboard_laporan_penghasilan and callbackbot_line_account. here it can be seen that the tables are related to each other based on the information required by certain tables.

\subsection{Application Testing}

At this stage, two tests will be carried out, namely the application trial by conducting some testing on the website application that has been made to determine the feasibility of the application made and UAT (User Acceptance Test) analysis using a questionnaire to see user respondents using the system that been design.

\section{Literature Study}

The theory uses in this study is from journal and documentation from library that it used to support on building the system.

\subsection{RouterOS-api.}

RouterOs-api is library that design to be use by python programming language that made by the social wifi group, which can be used to visualize the information on the mikrotik device and can add or update data on the mikrotik device by using the commands provided the library provide. 


\subsection{Mikrotik User Profile.}

Mikrotik user profile is a feature from mikrotik that used for to distributed certain of profile that will be used for every user account that been made in mikrotik hardware to manage its upload and download rate limit or set time based off date or bandwidth that the admin give to user account to access the network [8].

\subsection{Line messanger api}

Line messenger api is an API (Application Programming Interface) owned by line to be used so that other developers can design bots that can serve users who add this bot as friends on the social media line messenger application [9].

\subsection{Chabot}

Chabot is a system that can reply to messages sent by users. Chabot is composed of two words, namely chat and bot. Chat is communication carried out through written media or messages. A bot is a program that has knowledge that can respond according to commands given. Chabot can provide information quickly and efficiently. Chabot can chat with humans or other Chabot. There are many methods used in Chabot, such as the AIML framework, the patternmatching method, sentence similarity measurement and other matching methods [10] .

\subsection{Django Background Task}

Django background task it is a library that it used for as a scheduler to update function or namely task for every waiting task in this library it will be saved to the database to the log table and waiting for it turn to run.

\subsection{Ngrok}

Ngrok is an application that serves to expose local servers to the public network through a secure tunnel. By using ngrok, your local server will be accessible online through the internet. Ngrok application is very suitable for the needs of "Testing" or "Demo" a web without having to deploy to real hosting [11].

\section{Result and Discussion}

In this section will discuss about several tests that been carried out, namely testing the purchase of point packages, testing web chat, testing of buying internet packages through Chabot's, testing of making single-use vouchers and also using a UAT (User Acceptance Test) analysis using a questionnaire to see user and admin responds using the system.

\subsection{Testing Purchase of Point Packages}

Purchase of Point Packages is a process that done by new user or old use to add more point to their account to be use for buying internet packages that provide in Chabot by admin. Following figure is a step that used for doing this type of process.

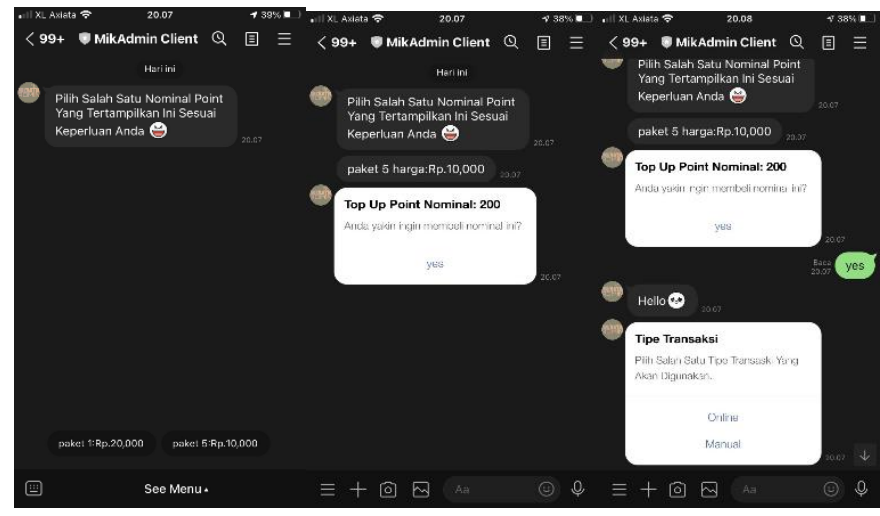

Figure 8 Puchases of Point Packages 
Figure 8 shown the process of this feature from left where user will choose the packets point they want that will shown two button each time if they agree to buy the packets that is button to show the point they will buy and second button to choose type of transaction they want that is manual and online.
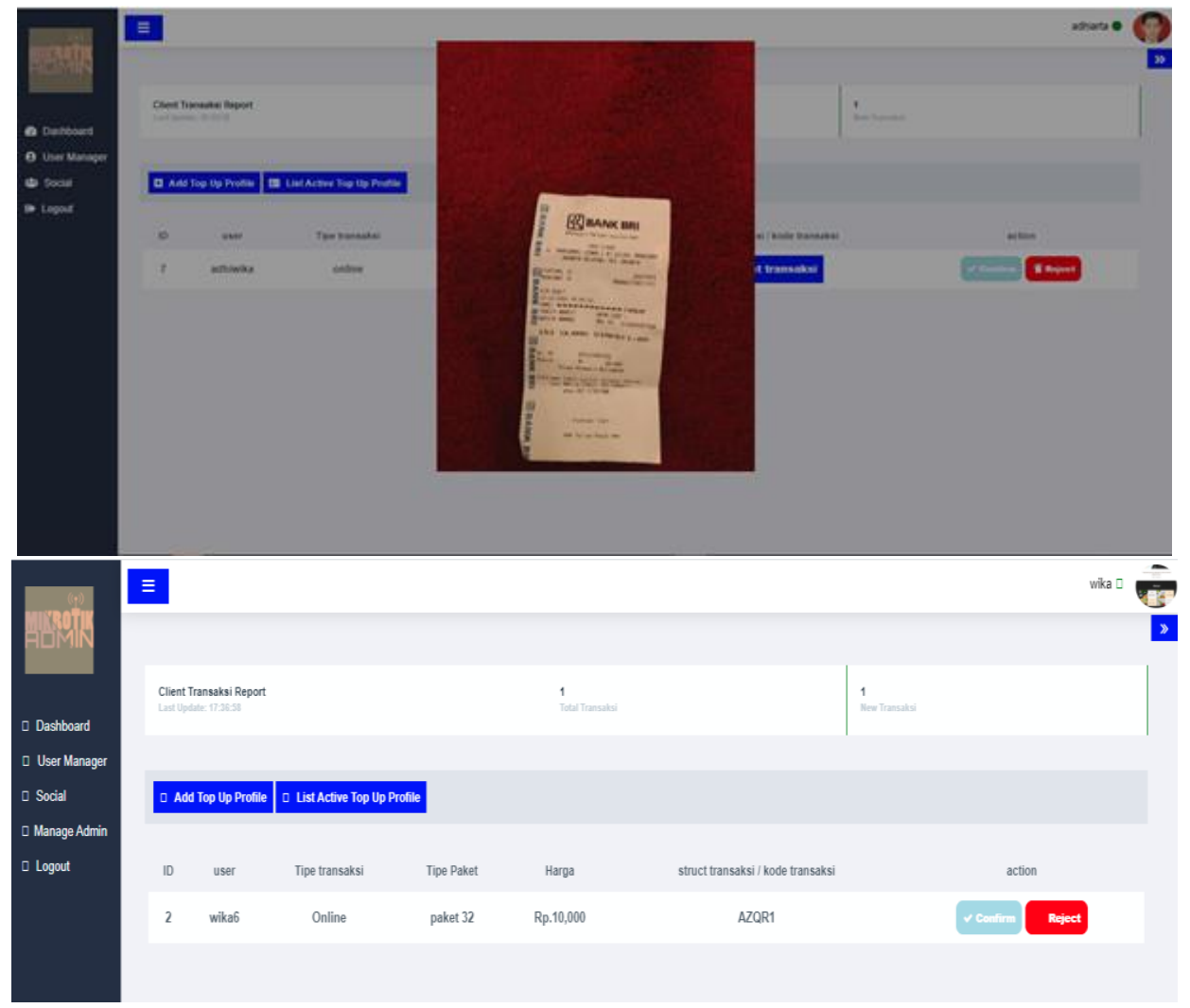

Figure 9 View of the two type transaction

Figure 9 shown the two type of transaction from the feature, that is online transaction that will guide user to send an image of the transaction to the owner bank account with the nominal that it choose and the manual application will send a transaction code for user to give to the admin and each of this transaction will be seen by admin if it valid or not.

\subsection{Testing Web Chat}

Web chat is an application that can be accessed through right side bar, this chat application is an application used by admins to chat with users via the admin website regarding problems users have when using this internet service. The following figure is a step that is carried out in this process.
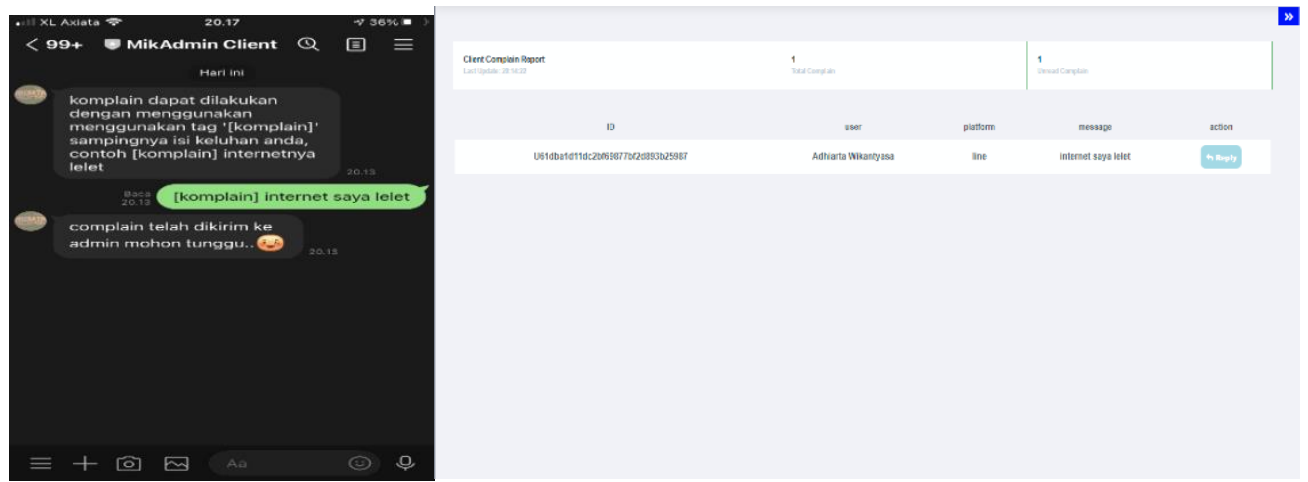

Figure 10 Complain request from user 
Figure 10 shown the first step of this feature that is start by user use the tag "[komplain]" to send the complain that it had about the service and this request will shown in website admin too wait for the admin to read it.

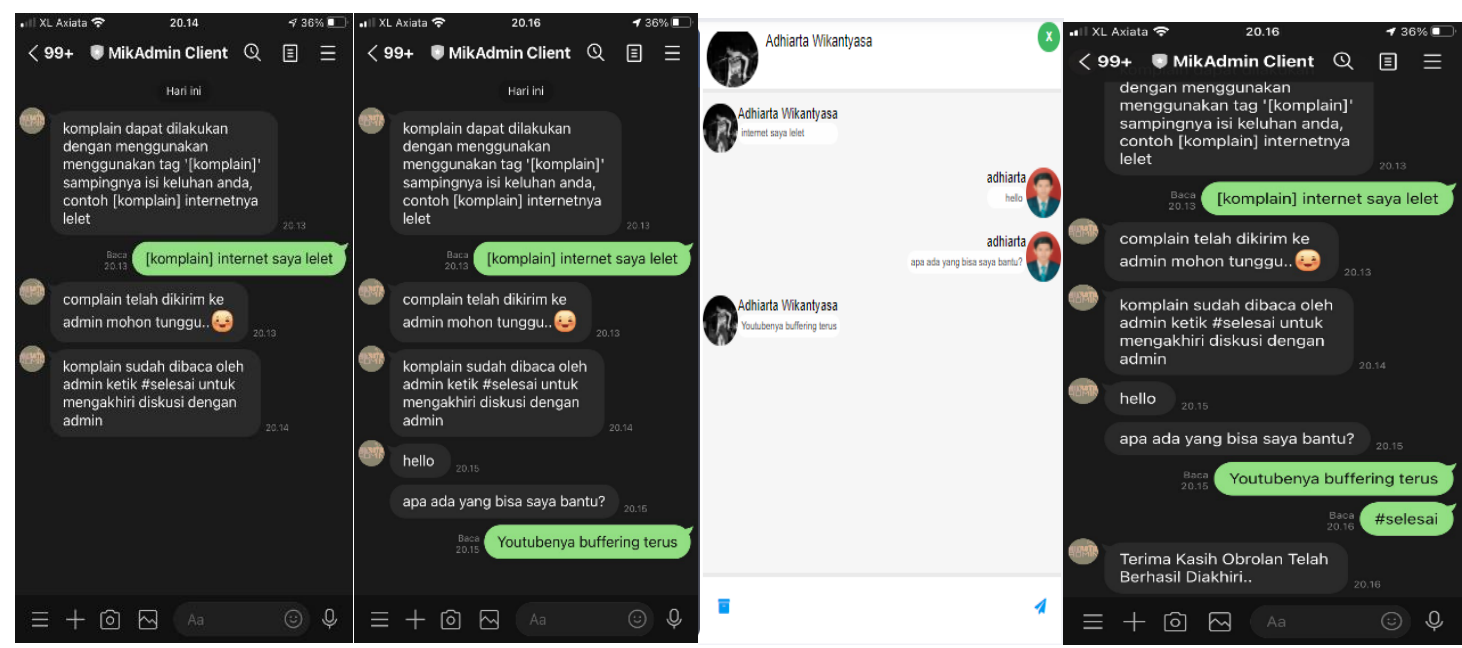

Figure 11 View of conversation

Figure 11 shown the conversation when the admin read the request that it send by the user that shown side by side from the chatbot application and the web chat how the message will display and at the right the end image shown the user closed the conversation by using tag "\#selesai".

\subsection{Purchasing of internet package}

Purchasing of internet package is a process that is carried out by users when they have sufficient nominal of points to buy one of the internet packages available on the chat bot to update their internet packages to access the internet services.

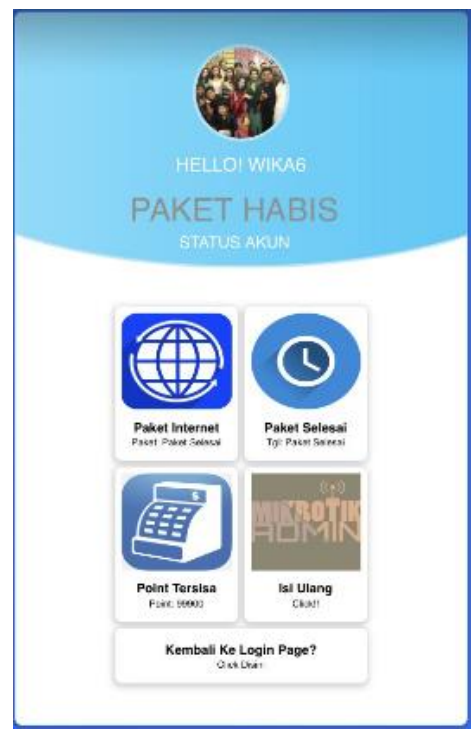

Figure 12 View Status Account

Figure 12 shown the status of packets user right now that it show there's no packets available right now and it shown the status of the account right now that is "PAKET HABIS" from this view the application guide user to update its packets to use the service. 


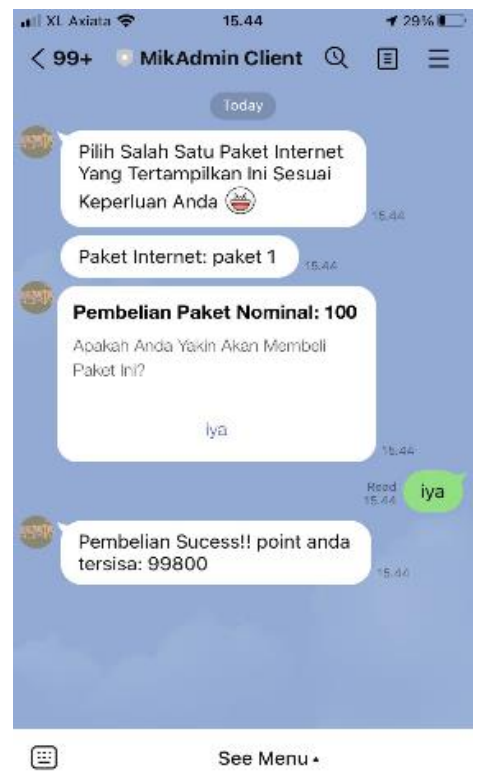

Figure 13 Puchases of Internet Packages

Figure 13 shown the steps to use this feature that is from the user choosing the internet packets that they want and the application will shown button to confirm the transaction of the packets if the point user have is valid to the nominal that it choose transaction will shown a success message.

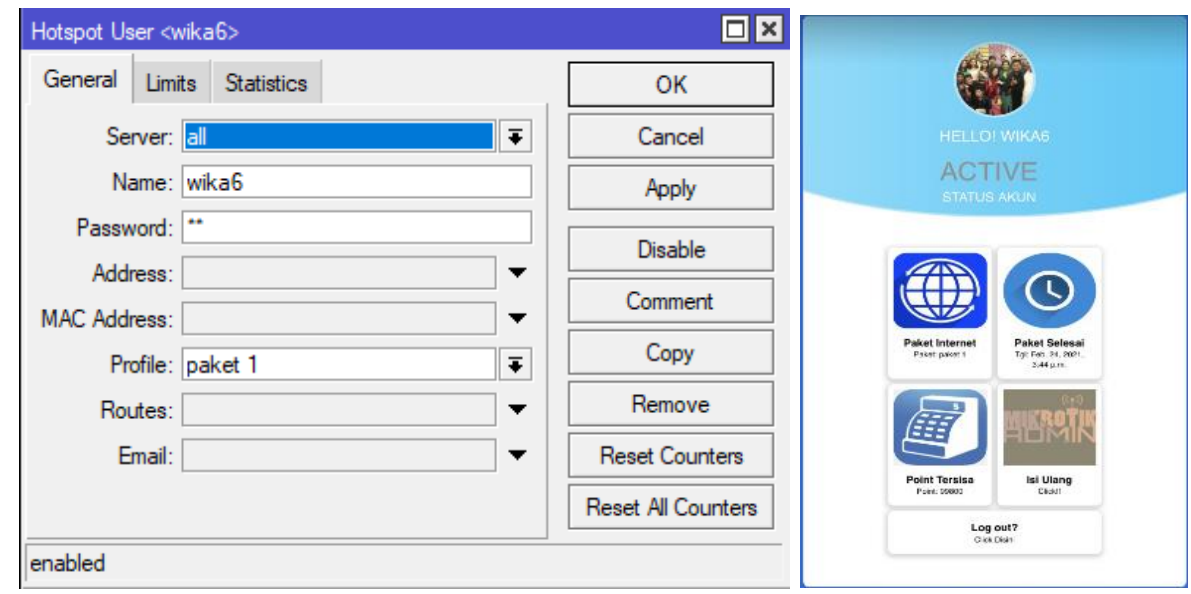

Figure 14 View status account from mikrotik and status page

Figure 14 shown side by side view of the new packets that the user bought from the right it shown from the mikrotik view the account packets have been update and the right image shown the status have been update to "active" and the new packet internet have shown with the expired date of the packets from this figure stated that user can access the network now.

\subsection{Analysis Result of UAT Testing.}

UAT (User Acceptance Test) is a testing process carried out by users with the output of a test result document that can be used as evidence that the software has been received and has met the requested needs [12]. UAT is not really that far difference to questionnaire bygiving a questionnaire is done to get responses from users regarding the bot messenger line application that been made, the questionnaire contains 11 questions where the questions consist of a measuring scale starting from level 1 (poor), level 2 (average), level 3 (good) and level 4 (excellent). The questionnaires were distributed and assessed by 14 user respondents who were 
obtained through the application of this system in two places. Following table is a result through this testing.

Table 1 Result test UAT

\begin{tabular}{|c|c|c|c|c|c|}
\hline No & Question & $\begin{array}{c}1 \\
\text { (poor) }\end{array}$ & $\begin{array}{c}2 \\
\text { (average) }\end{array}$ & $\begin{array}{c}3 \\
\text { (good) }\end{array}$ & $\begin{array}{c}4 \\
\text { (excellent) }\end{array}$ \\
\hline 1. & $\begin{array}{l}\text { Does the given menu make it } \\
\text { easier for you to choose the } \\
\text { features you want? }\end{array}$ & 0 & 1 & 6 & 7 \\
\hline 2. & $\begin{array}{l}\text { Are the instructions from the } \\
\text { chatbot easy for users to } \\
\text { understand? }\end{array}$ & 0 & 1 & 11 & 2 \\
\hline 3. & $\begin{array}{l}\text { Does this chatbot make it easy } \\
\text { to purchase internet package } \\
\text { transactions online? }\end{array}$ & 0 & 1 & 8 & 5 \\
\hline 4. & $\begin{array}{l}\text { In your opinion, does the online } \\
\text { chat feature with admin make it } \\
\text { easy for you to solve your } \\
\text { problem? }\end{array}$ & 0 & 0 & 8 & 6 \\
\hline 5. & $\begin{array}{l}\text { After using this application, has } \\
\text { the information about the top up } \\
\text { package or the available internet } \\
\text { been delivered quickly to the } \\
\text { customer? }\end{array}$ & 0 & 0 & 10 & 4 \\
\hline 6. & $\begin{array}{l}\text { Does this application display } \\
\text { information that is clear enough } \\
\text { and easily understood by } \\
\text { customers on each feature } \\
\text { used? }\end{array}$ & 0 & 1 & 5 & 8 \\
\hline \multirow[t]{2}{*}{7.} & $\begin{array}{l}\text { What do you think about your } \\
\text { assessment after using this } \\
\text { chatbot, is the online }\end{array}$ & & & & \\
\hline & $\begin{array}{l}\text { conversation feature between } \\
\text { users and admin working } \\
\text { properly? }\end{array}$ & 0 & 1 & 6 & 7 \\
\hline \multirow[t]{2}{*}{8.} & $\begin{array}{l}\text { What do you think about the } \\
\text { appropriateness of using this } \\
\text { application to provide } \\
\text { information and as a transaction }\end{array}$ & & & & \\
\hline & $\begin{array}{l}\text { medium for purchasing internet } \\
\text { packages? }\end{array}$ & 0 & 2 & 6 & 6 \\
\hline 9. & $\begin{array}{l}\text { In your opinion, is this } \\
\text { application more practical as a } \\
\text { transaction medium for } \\
\text { purchasing internet packages? }\end{array}$ & 0 & 2 & 8 & 6 \\
\hline \multirow[t]{2}{*}{10.} & $\begin{array}{l}\text { Currently purchasing internet } \\
\text { packages on rt / rw net services } \\
\text { still uses the manual method, } \\
\text { namely through paper / } \\
\text { vouchers, in your opinion, can } \\
\text { this application replace it as a } \\
\text { transaction medium? }\end{array}$ & 0 & 2 & 8 & 6 \\
\hline & \begin{tabular}{|c|} 
Total score \\
Percentage score \\
\end{tabular} & $\begin{array}{c}0 \\
0 \% \\
0\end{array}$ & $\begin{array}{c}11 \\
7,64 \% \\
\end{array}$ & $\begin{array}{c}76 \\
52,77 \%\end{array}$ & $\begin{array}{c}57 \\
39,58 \% \\
\end{array}$ \\
\hline
\end{tabular}

Based on the results of the UAT (User Acceptance Test) which can be seen in table above, it shows that from 14 respondents consisting of 11 questions, it can be seen that the highest value obtained on the measuring scale was 76 points with a percentage of $52.77 \%$ which means GOOD, 
then followed with a total of 57 points with a percentage of $39.58 \%$ which means VERY GOOD, then there are 11 points that were delayed, namely 27 points with a percentage of $7.64 \%$ which means GOOD ENOUGH, and then with 0 points with a percentage of $0 \%$, namely LESS GOOD. The conclusion from the UAT results can state that the application is good at delivering existing features and making it easier for users to use this application.

\section{Conclusion}

The conclusions obtained from the system created are that the tests carried out have stated that the system is capable of providing user needs in this $\mathrm{rt} / \mathrm{rw}$ net service such as providing onetime use internet vouchers, purchasing point packages, purchasing internet packages and handling chat with experienced users. Problems and apart from that, also getting results from conducting UAT (User Acceptance Test) in two place that is pondok cendana and the dalung permai housing, from the result of this testing stated that the application is capable in helping users interact with network admins and making it easier for users to buy internet package buy transactions online without having to meet the network admin to buy internet packages.

\section{References}

[1] K. Yudi Mulyanto, “ANALISIS DAN PENGEMBANGAN INFRASTRUKTUR JARINGAN KOMPUTER DALAM MENDUKUNG IMPLEMENTASI SEKOLAH DIGITAL," Jurnal JINTEKS , vol. 1, no 1, pp. 58 - 67, 2019.

[2] F. H., "Internet Murah dengan Membangun Jaringan RT-RW Net," Jurnal Teknologi Informasi DINAMIK, vol. XIII, nº 2, pp. 98-114, 2018.

[3] M. A. M. T. A. Z. Ahmad Tantoni, "Analisis Dan Implementasi Jaringan Komputer Brembuk.Net Sebagai Rt/Rw.Net Untuk Mendukung E-Commerce Pada Desa Masbagik Utara," Jurnal MATRIK, vol. $19, \mathrm{n}^{\circ} 2$, pp. 312-320, 2020.

[4] A. P. Tiara Sukma Fitria, "IMPLEMENTASI GENERATE VOUCHER HOTSPOTDENGAN BATASAWAKTU (TIME BASED) DAN KUOTA (QUOTA BASED) MENGGUNAKAN USER MANAGER DI MIKROTIK," Jurnal Manajemen Informatika, vol. 8, $\mathrm{n}^{\circ}$ 2, pp. 18-24, 2018.

[5] I. G. B. S. I. K. A. A. Kadek Oky Sanjaya, "Perancangan Sistem Informasi Surat Menyurat Terintegrasi (SUMATRI)Berbasis Website dan Android," JURNAL ILMIAH MERPATI, vol. 8, n 3, pp. 222 - 231, 2020.

[6] H. F. W. a. s. Reynaldi r. benedictus, "Rancang Bangun Chatbot Helpdesk untuk Sistem Informasi Terpadu Universitas Sam Ratulangi," E-Journal Teknik Informatika, vol. 11, nº 1, 2018.

[7] I. M. G. S. A. Ni Kadek Ariasih, "Rancang Bangun STIKIClass Facilities E-Complaint," LONTAR KOMPUTER, vol. 8, n 2, pp. $101-111,2017$.

[8] E. S. L. Hidayat, "PERANCANGAN DAN IMPLEMENTASI USER MANAGER PADA HOTSPOT MIKROTIK MENGGUNAKAN METODE QUEUE TREE TIPE PCQ," Jurnal JARKOM , vol. 7, n 2, pp. 112 - $120,2019$.

[9] M. R. M. Dimas Pratama Jati, "THE DEVELOPMENT OF CHATBOT APPLICATION ON LINE MESSAGING PLATFORM FOR CUSTOMER SERVICE IN JOGJA SEWA KAMERA," Complier, vol. 7, no 2, pp. $91-98,2018$.

[10] I. M. S. a. I. K. G. D. P. I. N. S. Paliwahet, "Pencarian Informasi Wisata Daerah Bali Menggunakan Teknologi Chatbot," Lontar Komputer, vol. 8, n 3, pp. 144-154, 2017.

[11] H. K. ,. H. A. K. ,. M. R. A. ,. M. A. R. Rizky Parlika, "IMPLEMENTASI AKSES MYSQL DAN WEB SERVER LOKAL MELALUI IMPLEMENTASI AKSES MYSQL DAN WEB SERVER LOKAL MELALUI JARINGAN INTERNET MENGGUNAKAN NGROK," JIKO (Jurnal Informatika dan Komputer), vol. 3, n 3, pp. 131-136, 2020 .

[12] I. M. S. K. S. W. Defri Gentia, "Rancang Bangun ChatbotSebagai Penghubung Komunikasi Antara Aplikasi Line Messenger Dengan Telegram Messenger.," JURNAL ILMIAH MERPATI, vol. 8, nº 3, pp. $156-167,2020$. 